\title{
High resolution analysis of fossil pigments, carbon, nitrogen and sulphur in the sediment of eight European Alpine lakes: the MOLAR project
}

\author{
Andrea LAMI*, Piero GUILIZZONI and Aldo MARCHETTO \\ C.N.R. Istituto Italiano di Idrobiologia, Largo Tonolli 50, 28922 Verbania Pallanza, Italy \\ *e-mai corresponding author: a.lami@iii.to.cnr.it
}

\begin{abstract}
A palaeoenvironmental reconstruction for the past 2-3 centuries of eight remote sites from northern to southern Europe was based on a number of palaeolimnological proxies, especially fossil pigments. Most of the lakes studied are located above the timberline and a great effort centred on the creation and analysis of a data-sets of sedimentary records. A chronology for the last century was based on radiometric techniques $\left({ }^{210} \mathrm{~Pb},{ }^{241} \mathrm{Am}{ }^{137} \mathrm{Cs}\right)$. The accumulation rate of recent sediment was found to vary from $0.041 \mathrm{~cm} y^{-1}$ (Lake Saanajärvi, Finland) to $0.14 \mathrm{~cm} \mathrm{y}^{-1}$ (Jezero v Ledvici, Slovenia). During the time-span represented by the cores were the major changes in organic carbon and nitrogen in Nižné Terianske Pleso (Slovakia), Redó (Spain) and Gossenköllesee (Austria). Constant increase of these nutrients from AD 1900 onwards was shown in lakes Saanajärvi, Nižné Terianske Pleso and Hagelseewli (Switzerland). No common trends in sulphur concentrations was evident. There is evidence of an atmospheric input of sulphur in Hagelseewli. This lake shows the highest concentrations, 10 fold higher at surface than the other lakes (ca $6 \%$ d.m.). A decrease of $S$ during very recent times is clearly shown by the cores from Redo and Hagelseewli: this might be related to the reduction in the atmospheric loading (the matching of the atmospheric and sedimentary sulphur trends favours this hypothesis). Concentrations of total pigments and HPLC single carotenoids and chlorophylls showed marked fluctuations throughout the cores of all lakes. High pre-AD 1800 pigment concentrations were detected in Nižné Terianske Pleso, Redó, Hagelseewli and Gossenköllesee. During the last ca 50 years an increase in productivity inferred from fossil pigments is shown by Øvre Neådalsvatn (Norway), Nižné Terianske Pleso, Saanajärvi and Jezero v Ledvici. Except Gossenköllesee (Kamenik et al. 2000, this issue). Significant catchment disturbances are absent in these remote environments, so these increases can be considered to be the result of temperature increase or atmospheric nutrient pollution. Carotenoids belonging to sulphur anaerobic photosynthetic bacteria of the green and red groups (Chlorobiaceae and Chromatiaceae) were found in three lakes, i.e. Jezero $v$ Ledvici, Hagelseewli and Gossenköllesee, implying that these lakes experienced seasonal anoxia in their bottom waters with strong stratification.
\end{abstract}

Key words: geochemistry, pigments, Alpine lakes, sediment

\section{INTRODUCTION}

This study is part of the Mountain Lakes Research (MOLAR), Workpackage 3: "climate variability and ecosystem dynamics at remote alpine and arctic lakes". The overall scope of the MOLAR project was to understand the function and to identify the response of biological communities living in remote alpine environments to perturbation related to long range transport of pollutants and to climate variability. Here remote lakes are defined as those lying above or beyond the timberline. The specific objective of the WP3 was to assess underlying trends and natural variability in climate from the fine-detail analysis of sediment cores taken from the study sites. These lakes were selected because they were supposed to be one of the most sensitive ecosystems to atmospheric pollution and climate variability. This sensitivity is related to the brief growing season that, despite high mid-summer productivity in some of these systems, ensures annual production is low relative to tropical and temperate lakes. Additionally, chemical weathering rates are climate-dependent factors that regulate in part the nutrient supply to lakes (Smol et al. 1991).
Here, we present the results of the analysis of plant pigment remains (algae and sulphur photosynthetic bacteria) in several alpine lakes on which a palaeolimnological studies under a common protocol was performed.

Evaluation of the effects of anthropogenic and climatic changes on lakes biota requires long term records of the physical, chemical and biological environment. For most of the ecosystems, especially the alpine, remote lakes, only palaeolimnology can supply this information. Among the possible proxy records that can be used in a sediment core study, pigments are often the sole fossil remains of non-siliceous algae. It is well estabilished that photosynthetic pigments (e.g. chlorophyll- $a$ ) are a reliable proxy of modern algal biomass. Especially during the last two decades, they have also been used extensively to assess algal biomass in palaeolimnological studies.

Sedimentary pigments have also been proved valuable indicators of past trophic conditions and can yield approximate indices for bioproductivity (Züllig 1982; Guilizzoni et al. 1983; Sanger 1988; Leavitt 1993). Moreover, chlorophylls and associated carotenoid pigments are being used to map the chemotaxonomic composition 


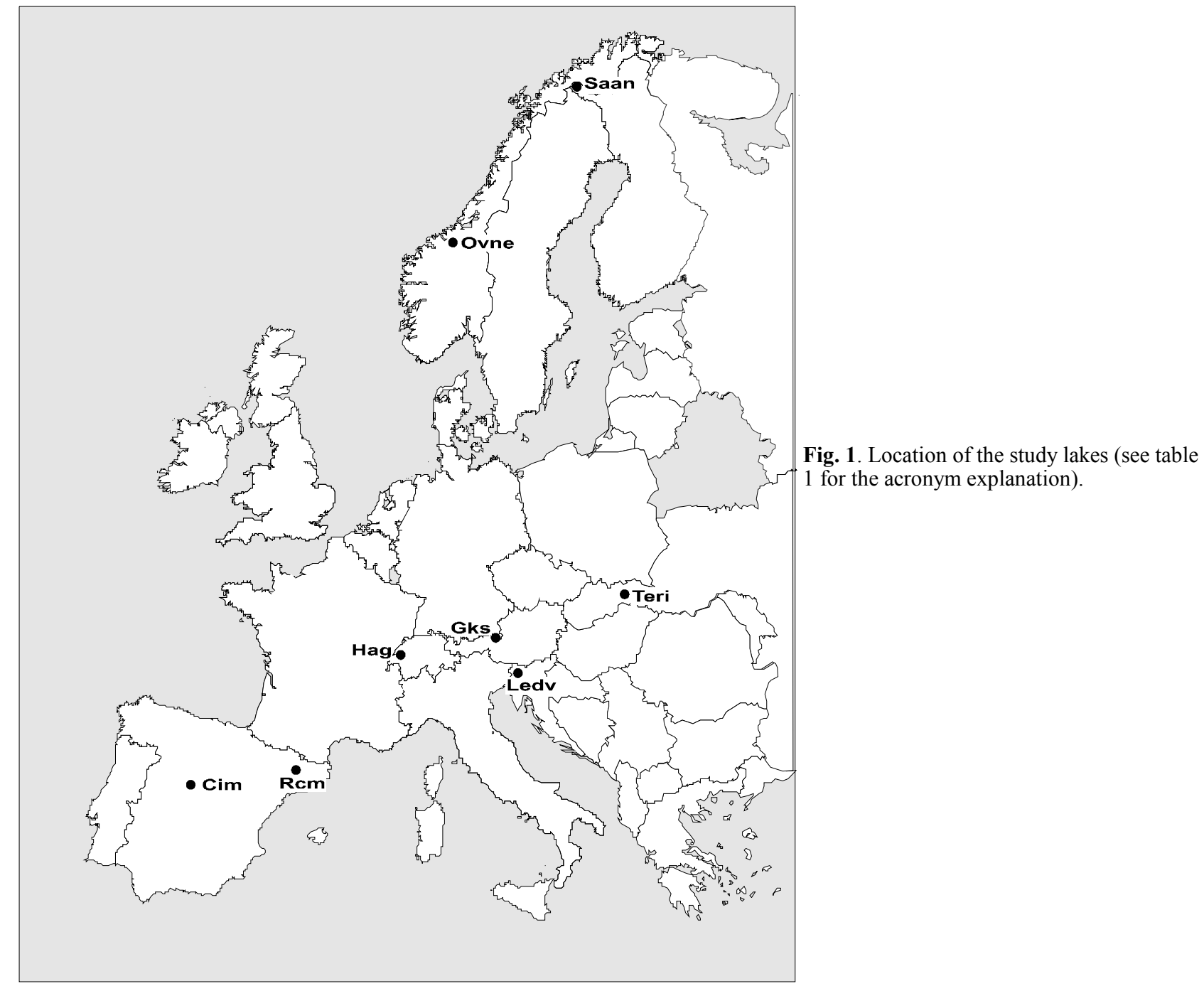

of phytoplankton in marine and lake samples (Jeffrey et al. 1997 and references therein; Lami et al. 1992). Thus, taking into account a number of biological, physical and chemical factors that influence their deposition and abundance (Leavitt 1993; Cuddington \& Leavitt 1999), the pigments are useful as indices of present and past trophic conditions (Gorham et al. 1974; Guilizzoni et al. 1983; Swain 1985; Sanger 1988; Leavitt 1993; Leavitt et al. 1999), lake acidification (Guilizzoni et al. 1992), and climate changes (Smol 1990; Lami et al. 1996, 1997; Guilizzoni \& Lami 1999).

Plant pigments are relatively susceptible to early oxidative decomposition, but in productive lakes especially they tend to be well preserved because the sediment organic matter in such lakes is predominantly autochthonous, and rapid burial of the aquatic detritus from which it originates ensures early entry into an anoxic environment favourable for pigment preservation (Leavitt 1993).

The radiation absorption ratio $430 \mathrm{~nm}: 410 \mathrm{~nm}$ is an index of lake acidification (Guilizzoni et al. 1992) that can also be used as a measure of the quality of pigment preservation in cases where lakes are not acidified (as in the case of the study lakes). This index may be expected to bear some relation to the degree of conversion of chlorophyll to phaeopigments as expressed by the ratio of the optical density of an extract at $430 \mathrm{~nm}$ to that at $410 \mathrm{~nm}$. When in the sediment the values of the $430 \mathrm{~nm}: 410 \mathrm{~nm}$ ratios are around 1, i.e. close to those of an poorly degraded mixture of natural pigments, the preservation conditions are generally good.

\section{STUDY SITES AND CORING}

The eight sites selected for palaeolimnological research are shown in the figure 1 and table 1 . They are situated in remote areas almost all at high altitude in the Alps and Pyrenees above the timberline. Two high latitude lakes in Norway and Finland are the largest. None of these lakes is acidified. Many have poor or no fish population (Tab. 1). More detailed information on hydrology, catchment, water chemistry and biology of these lakes is reported elsewhere (Straškrabová et al. 1999). On each of these lakes, 3-5 cores were taken 
Tab. 1. Some morphometric characteristics of the lakes investigated. See Straškrabová et al. (1999) and reference therein for more details. * fishless.

\begin{tabular}{|c|c|c|c|c|c|c|c|c|c|}
\hline Lake & Core Acronym & Country & Latitude & Longitude & $\begin{array}{l}\text { Core length } \\
\quad(\mathrm{cm})\end{array}$ & $\begin{array}{l}\text { Lake alt. } \\
\text { (m a.s.1.) }\end{array}$ & $\begin{array}{l}\text { Lake } \\
\text { (ha) }\end{array}$ & $\begin{array}{l}\text { Max depth } \\
\text { (m) }\end{array}$ & $\begin{array}{l}\text { Mean depth } \\
\text { (m) }\end{array}$ \\
\hline Øvre Neådalsvatn & Ovne 97-5 & $\mathrm{N}$ & $62^{\circ} 46^{\prime} 30^{\prime \prime}$ & $09^{\circ} 00^{\prime} \mathrm{E}$ & 28.6 & 728 & 50.0 & 18.0 & 3.9 \\
\hline Gossenköllesee & Gks97-3 & $\mathrm{A}$ & $47^{\circ} 13^{\prime} 49^{\prime \prime} \mathrm{N}$ & $11^{\circ} 00^{\prime} 51^{\prime \prime} \mathrm{E}$ & 32.3 & 2417 & 1.7 & 9.9 & 4.7 \\
\hline Redó & Rcm97-1 & $\mathrm{E}$ & $42^{\circ} 38^{\prime} 34^{\prime \prime} \mathrm{N}$ & $00^{\circ} 46^{\prime} 13^{\prime \prime} \mathrm{E}$ & 42.6 & 2240 & 24.0 & 73.0 & 32.0 \\
\hline Nižné Terianske pl.o* & Teri96-6 & SK & $49^{\circ} 10^{\prime} \mathrm{N}$ & $20^{\circ} 00^{\prime} \mathrm{E}$ & 28.2 & 1941 & 4.8 & 44.4 & 18.4 \\
\hline Laguna Cimera & Cim97-1 & $\mathrm{E}$ & $40^{\circ} 15^{\prime} 50^{\prime \prime} \mathrm{N}$ & $05^{\circ} 18^{\prime} 15^{\prime \prime} \mathrm{W}$ & 24.4 & 2140 & 4.5 & 9.4 & 4.8 \\
\hline Jezero v Ledvici* & Ledv96-4 & SLO & $46^{\circ} 20^{\prime} 30^{\prime \prime} \mathrm{N}$ & $13^{\circ} 47^{\prime} 20 \mathrm{E}$ & 29.80 & 1830 & 2.4 & 15.0 & 5.7 \\
\hline Saanajärvi & Saan98-1 & SF & $69^{\circ} 05^{\prime} \mathrm{N}$ & $21^{\circ} 27^{\prime} \mathrm{E}$ & 10.2 & 679 & 70.0 & 24.0 & - \\
\hline Hagelseewli* & Hag96-2 & $\mathrm{CH}$ & $46^{\circ} 40^{\prime} \mathrm{N}$ & $08^{\circ} 02^{\prime} \mathrm{E}$ & 34.00 & 2339 & 3.0 & 18.5 & 8.3 \\
\hline
\end{tabular}

between 1996 and 1998, sliced at contiguous 0.2-0.25 $\mathrm{cm}$ intervals all the way down to the core bottom. This sub-sampling protocol provided an average sampling resolution of $c a$ 1-5 y. In one case, Lake Hagelseewli, (were the sediment accumulation rate was greater) core sectioning was performed on $0.5 \mathrm{~cm}$ basis. Following a standard scheme for each site, besides the plant pigments, organic carbon and nitrogen, sulphur that are discussed here, the following parameters were also analysed: dry mass, bulk organic matter (as loss-onignition), diatoms, chrysophytes, Cladocera and chironomid remains.

Dating was based on ${ }^{210} \mathrm{~Pb},{ }^{137} \mathrm{Cs}$ and ${ }^{241} \mathrm{Am}$ and performed in Liverpool, UK (Appleby 2000, this issue).

\section{METHODS}

In the present study, pigments were extracted using a basic method described by Lami et al. (1994). Total pigments (chlorophylls and their derivatives, CD; crude carotenoids, TC) were measured spectrophotometrically and the single specific carotenoids and chlorophylls by an HPLC system (Lami et al. 1994). Chlorophyll derivatives are expressed as spectrophotometric units per gram organic matter $\left(\mathrm{U} \mathrm{gOM}^{-1}\right)$ (Guilizzoni et al. 1983). The total and the single carotenoids are expressed as $\mathrm{mg}$ $\mathrm{g} \mathrm{OM}^{-1}$ and nmoles g LOI ${ }^{-1}$, respectively (Züllig 1985). The samples for plant pigment analysis were preserved deep-frozen until the analysis. A sub-sample of $c a 2 \mathrm{~g}$ wet sediment was weighted and extracted overnight with $c a 10 \mathrm{ml}$ of acetone/water 90:10. The extract was then centrifuged at $3000 \mathrm{rpm}$ for $10 \mathrm{~min}$ in a glass centrifuge tube and used for total pigments and for specific chlorophyll and carotenoid determinations through HPLC chromatography.

Spectrophotometric analysis: The acetone extract was read in a UV/VIS spectrophotometer (Perkin-Elmer Lambda 6); for each sample the absorption spectrum was recorded between $350 \mathrm{~nm}$ and $800 \mathrm{~nm}$. The total carotenoids and chlorophyll concentrations were calculated on a loss on ignition basis using the equation described in Züllig (1982) and Guilizzoni et al. (1983). From the UV/VIS spectra the 430nm: $410 \mathrm{~nm}$ ratio was also calculated (Guilizzoni et al. 1992).

Chromatographic analysis: The equipment used was a "Beckman System Gold " that consisted of an autosam- pler equipped with Rheodyne 7125 valve, a double pump module for gradient elution, a UV/VIS detector and a diode array detector A stainless steel column of 25 $\mathrm{cm}$ in length and $4.6 \mathrm{~mm}$ in internal diameter was used. The column was filled with a spherical silica resin of 5 $\mu \mathrm{m}$ diameter coated with octadecyl (C-18). Pigment detection was routinely recorded at $460 \mathrm{~nm}$ and at 656 $\mathrm{nm}$ for the determination of carotenoids and of chlorophylls, respectively.

The elution mixture was based on Mantoura \& Llewellyn (1983) with some modification. The solvent mixtures that give the better pigment separation was:

Solvent A: 80:20 methanol:water. To the water propionic acid and butyl-ammonium phosphate buffer was added as ion pairing agent with a final concentration of $1 \times 10^{-3}$ moles.

Solvent B: 60:40 acetone: methanol.

The initial condition for the analysis was flow rate 1 $\mathrm{ml} \mathrm{min} \mathrm{m}^{-1}$ and $15 \%$ of solvent $\mathrm{B}$. The elution programme was a linear gradient to $95 \%$ of B in 45 min with a parallel gradient of the flow rate from 1 to $2 \mathrm{ml} \mathrm{min}^{-1}$ followed by an isocratic elution up to $55 \mathrm{~min}$. Here the data acquisition is stopped and the system return to the initial condition. Before the injection of the next sample the system was re-equilibrated to the initial condition for $10 \mathrm{~min}$. All the solvent used were HPLC grade and used without any further purification other than degassing. Water was purified with a Milli-Q system.

Finally, organic carbon and organic nitrogen were measured by a CNS analyser (Carlo Erba mod. EA 1108).

\subsection{Pigment identification and quantification}

Pigments were identified by co-chromatography with authentic standards commercially available or with culture material purified by Thin Layer Chromatography (TLC). The available standards were donated by Hoffman La Roche, Switzerland or purchased from Water Quality Institute (VKI), Hørsholm, Denmark. All pigment data are expressed as a ratio to organic matter (LOI at $550{ }^{\circ} \mathrm{C}$ ), thus reflecting the degree of pigment preservation relative to that of the total organic matrix in which the pigment occurs. 
Tab. 2. Main indicator pigments and their taxonomic specificity (Davies 1976; Züllig 1982, 1985, 1986; Leavitt 1993).

\begin{tabular}{ll}
\hline Pigment & Taxa \\
\hline Alloxanthin & Cryptophytes \\
$\beta$-carotene & All plants, some photosynthetic bacteria \\
Astaxanthin & Invertebrate herbivores, some chlorophytes \\
Canthaxanthin & Invertebrate herbivores, some filamentous cyanobacteria \\
Echinenone & Cyanobacteria \\
Fucoxanthin & Siliceous algae \\
Lutein & Chlorophytes, Euglenophytes, Trachaeophytes \\
Myxoxanthophyll & Colonial and filamentous cyanobacteria \\
Oscillaxanthin & Oscillatoriaceae \\
Peridinin & Pyrrophytes \\
Zeaxanthin & Cyanobacteria \\
Diadinoxanthin & Siliceous algae \\
Dinoxanthin & Diatom specifically \\
Chlorophyll- $a$ & All plants \\
Chlorophyll- $b$ & Chlorophytes, Euglenophytes, Trachaeophytes \\
Chlorophyll- $c$ & Chrysophytes, Pyrrophytes \\
Phaeophorbide- $a$ & Chlorophyll- $a$ derivatives (grazing) \\
Phaeophytin a & Chlorophyll- $a$ derivative (general) \\
Isorenieratene & Green sulphur bacteria (Chlorobium sp.) \\
Okenone & Purple sulphur bacteria (Chromatium sp.) \\
Spheroidene & Rhodopseudomonas spheroides \\
Rhodopinal & Lamprocystis, Rhodospirillum tenue \\
\hline &
\end{tabular}

\subsection{Expression and interpretation of pigment data}

Often, in unproductive lakes such as the alpine lakes reported here, a larger proportion of sedimentary organic matter is allochthonous, and pigment are poorly preserved in this terrestrial detritus, owing to its longer exposure to oxidation at the soil surface. These usually clear water lakes also often have a thicker oxidised microzone at the mud surface and exhibit a slower rate of sediment accumulation, thus allowing greater pigment exposure to oxidation at the sediment surface. Even aquatic detritus may be subject to a considerable degree of oxidation in deeper lakes with a long and wholly aerobic water column.

Elevated concentrations of chlorophyll- $b$ suggest that this pigment was not derived from terrestrial sources because Chl- $b$ from land plants is degraded prior to deposition. If the MOLAR lakes have few macrophytes (e.g. mosses), the changes of Chl- $b$ concentrations are interpreted as indicating an increase in biomass of planktonic/benthic chlorophytes or euglenoid protists. Apart from the chlorophylls and their derivatives, the carotenoids were also studied (Tab. 2). $\beta$-carotene (present in all algae), lutein and chlorophyll- $b$ (specific of chlorophytes and macrophytes), the entire range of prokaryote carotenoids, echinenone, as well as myxoxanthophyll, oscillaxanthin. zeaxanthin, (all characteristic carotenoids of cyanobacteria) and the carotenoids of anaerobic sulphur photosynthetic bacteria (e.g. okenone, isorenieratene), were measured and expressed as nMoles per g organic matter.
A selection of bacterial pigments, and the organisms producing them, considered in this paper, include: okenone is a characteristic carotenoid of a sulphur photosynthetic bacteria named Chromatium (Chromatium spp. and Thiopedia spp.). This organism (which has been mainly described as planktonic, because occurred at the chemocline of stratified lakes) is present only in anoxic water, rich in $\mathrm{H}_{2} \mathrm{~S}$. Similarly, isorenieratene (Chlorobium species), OH-Spheroidene (this belongs to another bacteria, Rhodopseudomonas spp.) and Rhodopinal (belongs to the genus Thiodictyon) are specific carotenoids of bacteria that live under strictly anoxic conditions, $\mathrm{H}_{2} \mathrm{~S}$, and have light dependent metabolism. Some authors interpret the $\mathrm{OH}$-spheroidene profiles as the onset of meromictic conditions (e.g. Züllig 1985). The occurrence of okenone and isorenieratene provides evidence for permanent or transitory anoxic conditions at the sediment surface or at the sediment-water interface (Züllig 1986). Isorenieratene, which typically form the deepest photosynthetic layer in lakes, can be drastically reduced by shading from the overlying population, Thus, the relative increase of okenone compared to isorenieratene can be interpreted as an increase in lake in lake primary productivity and a decrease in water transparency (Brown et al. 1984).

\section{RESULTS}

\subsection{Nitrogen, carbon and sulphur (Fig. 2)}

Organic nitrogen, carbon and total sulphur distributions are similar and well correlated within all lakes (P $\leq 0.01$; cf. Fig. 9). 

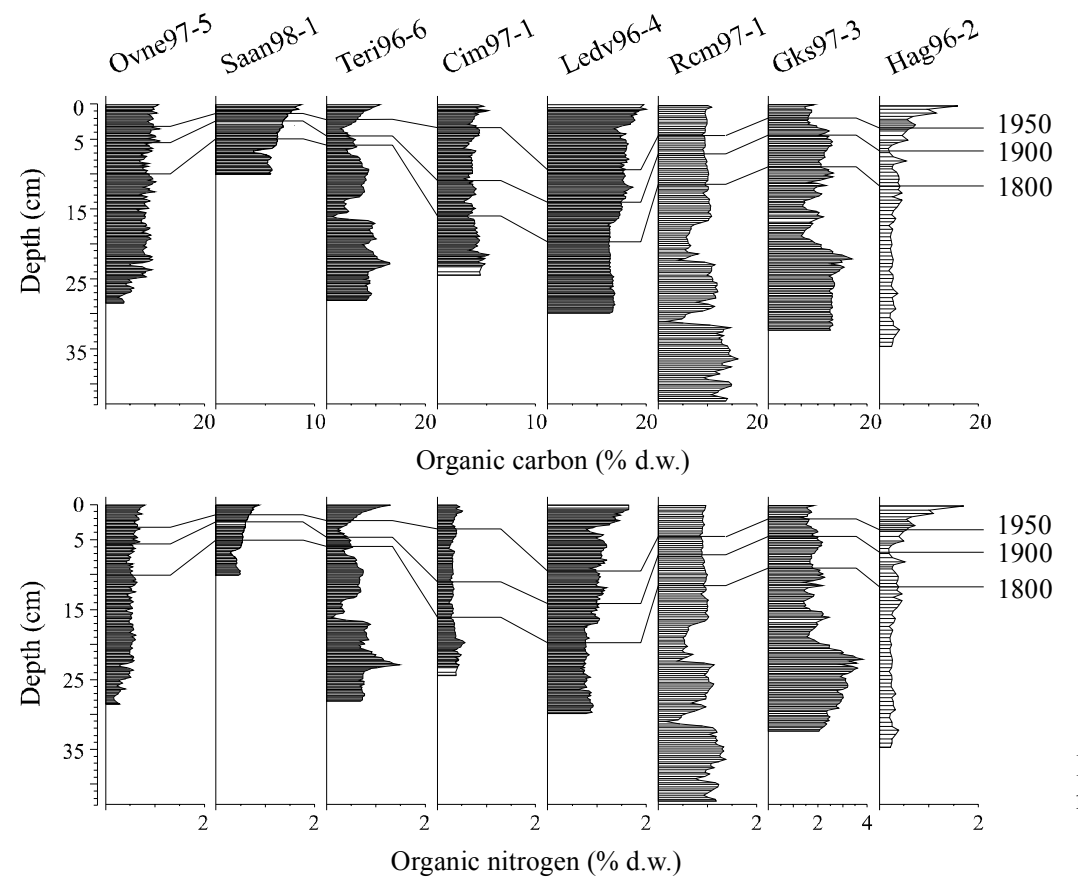

Fig. 2. Depth profiles of organic carbon, nitrogen and sulphur in the study lakes (see table 1 for an explanation of the core codes).
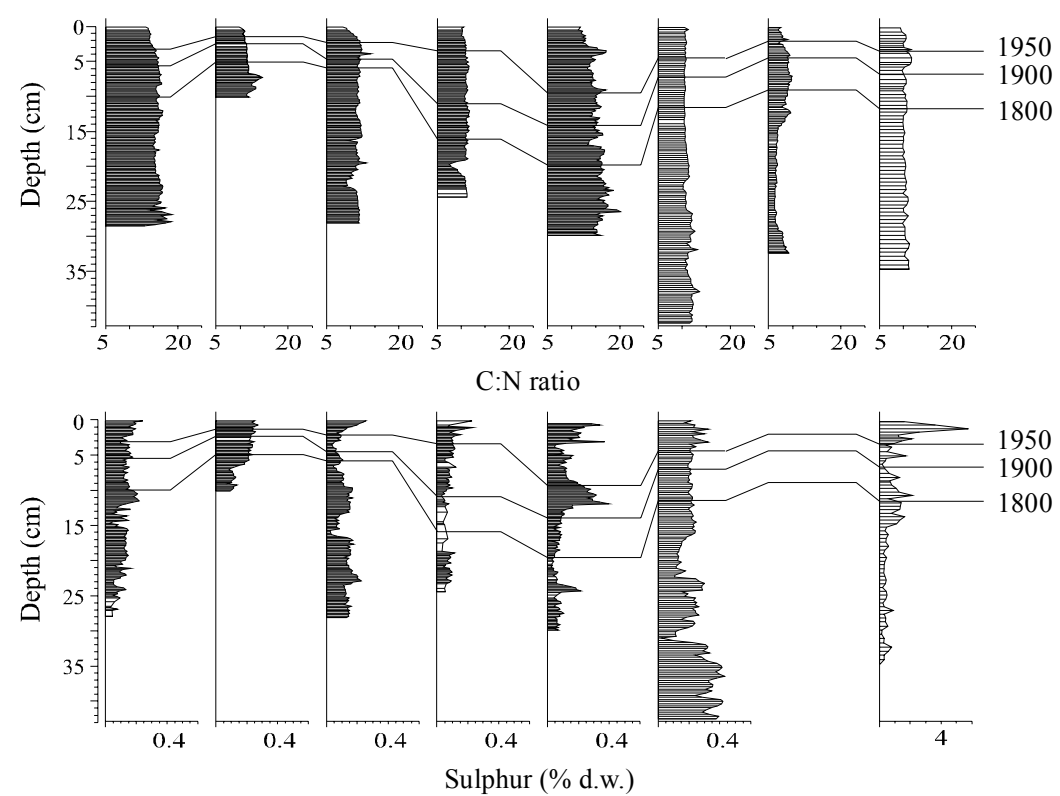

Lakes showing recent nitrogen concentrations $\geq 1 \%$ are: Nižné Terianske, (Teri96-6), Redó (Rcm97-1), Gossenköllesee (Gks97-3), Jezero v Ledvici (Ledv 964), and Hagelseewli (Hag96-2). All lakes, except Saanajärvi (Saan98-1) and Cimera (Cim97-1) show recent carbon concentrations $\geq 10$. Rather regular profiles of $\mathrm{N}$ and $\mathrm{C}$ are shown in lakes Øvre Neådalsvatn (Ovne97-5), Jezero v Ledvici (Ledv96-4), and Saanajärvi (Saan981). The remaining lakes show more or less pronounced fluctuations. An increase during last century, mostly in the last 40-50 years, of $\mathrm{N}$ and $\mathrm{C}$ is shown by Jezero $\mathrm{v}$ Ledvici (slightly), Saanajärvi (slightly), Cimera (slightly), Hagelseewli (marked) and Nižné Terianske (marked). In all of these lakes a parallel increase of total pigment concentrations (see below) is observed. The remaining lakes do not show a $\mathrm{N}$ and $\mathrm{C}$ increase or, in one case (Gks97-3; Gossenkölle), these nutrients decrease during the past few decades.

Pre-AD 1800 high concentrations, higher that present century, of $\mathrm{C}$ and $\mathrm{N}$ are evident in Nižné Terianske, Redó (in this lake a sharp decrease of $\mathrm{C}$ and $\mathrm{N}$ concentrations as well as pigments is noted from $22 \mathrm{~cm}$ to 17 $\mathrm{cm})$ and especially Gossenköllesee.

The C: $\mathrm{N}$ ratio indicates that the sedimentary organic matter is predominantly autochthonous (mean of $\mathrm{ca} 10$; see Lami et al. 1994, and Meyers \& Lallier-Vergès 1999 for discussion of this ratio) as is commonly the case for aquatic systems above the timberline. The only 

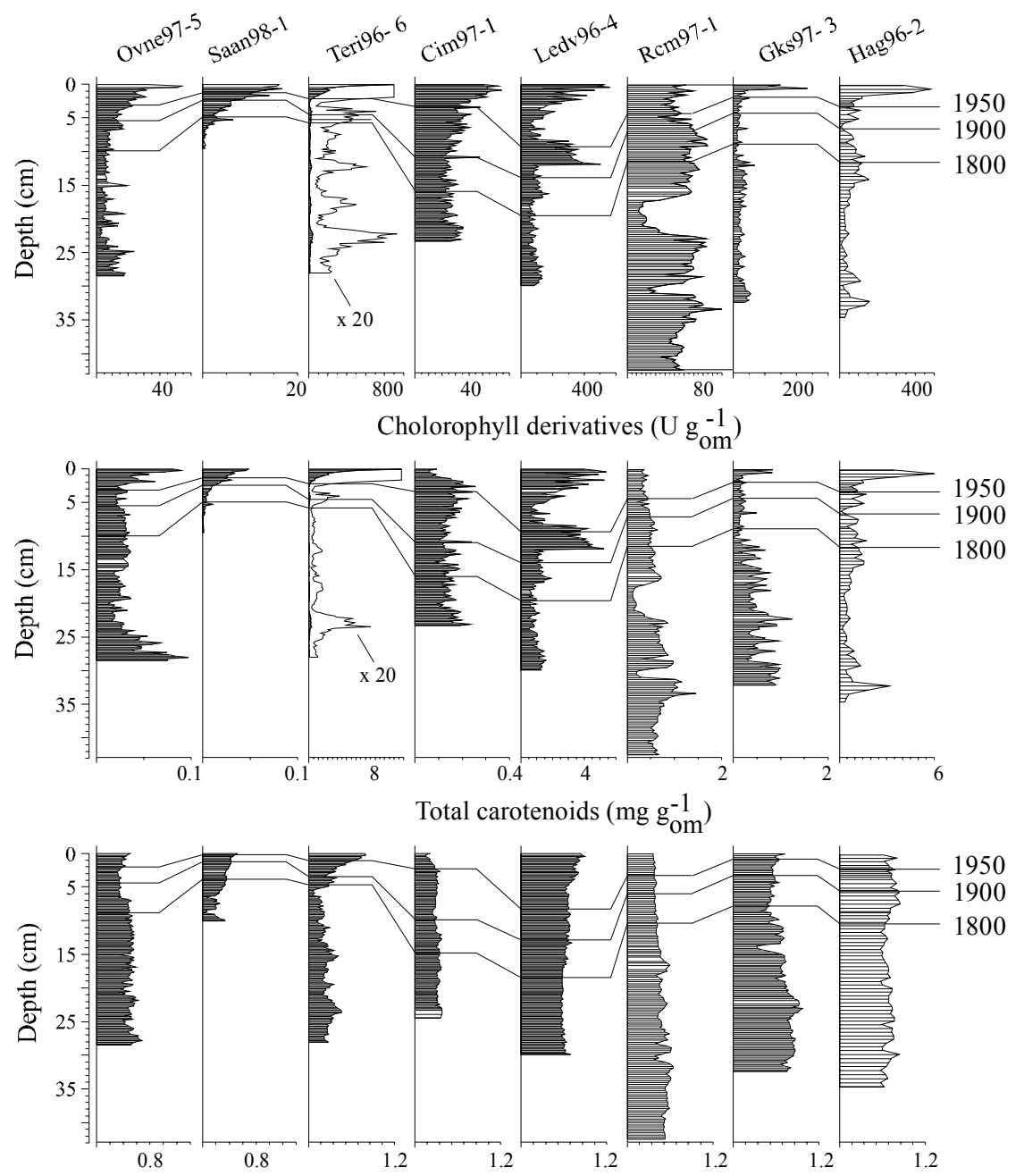

430nm:410nm

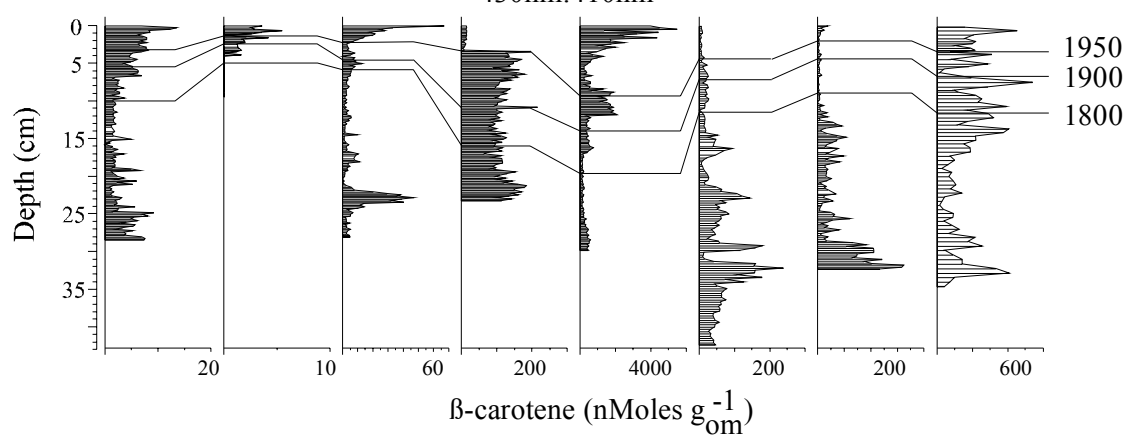

Fig. 3. Depth profiles of the concentration of total pigments (Chlorophyll derivatives and total carotenoids) and $B$-carotene in the study sediment cores (see table 1 for an explanation of the core codes). The ratio between absorbance at $430 \mathrm{~nm}$ and at $410 \mathrm{~nm}$, an index of pigment degradation, is also shown. exceptions are cores from: Øvre Neådalsvatn (Ovne975; mean ratio of ca 18), Saanajärvi (Saan 98-1), Nižné Terianske (Teri96-6) and Redó (RCM) which have mean values of 11-12. For these lakes alpine meadows cover quite a large area of the lake's catchment (Staškrabová et al. 1999). However, it is a difficult task to disentangle allochthonous vs autochthonous contributions to the sedimentary pool in these environments. In fact, low $\mathrm{C}: \mathrm{N}$ ratios ( $\mathrm{ca}$ 8) were reported in high altitude alpine soils (D'Alessio et al., pers. comm.).

For all lakes the C:N profiles do not show significant changes through time: only in Saan 98-1 this ratio is very regular during the last century ( $c a 12$ ), whereas prior to $1900 \mathrm{AD}$ the values are slightly higher. In Nižné Terianske (Teri96-6), a slighty decrease is observed from $2 \mathrm{~cm}$ to the core top, whereas in Cimera (Cim97-1) a trough is evident at $c a 20 \mathrm{~cm}$.

Many complex factors control the incorporation of $\mathrm{S}$ into sediments (see for example Mitchell et al. 1990 for a detailed discussion about this element in sediments). The highest concentrations (10 fold higher at surface than the other lakes) are from core Hagelseewli ( $c a 6 \%$ d.m.); all the remaining lakes show a concentration below $1 \% \mathrm{~d} . \mathrm{m}$. A clear recent increase of $\mathrm{S}$ concentrations 

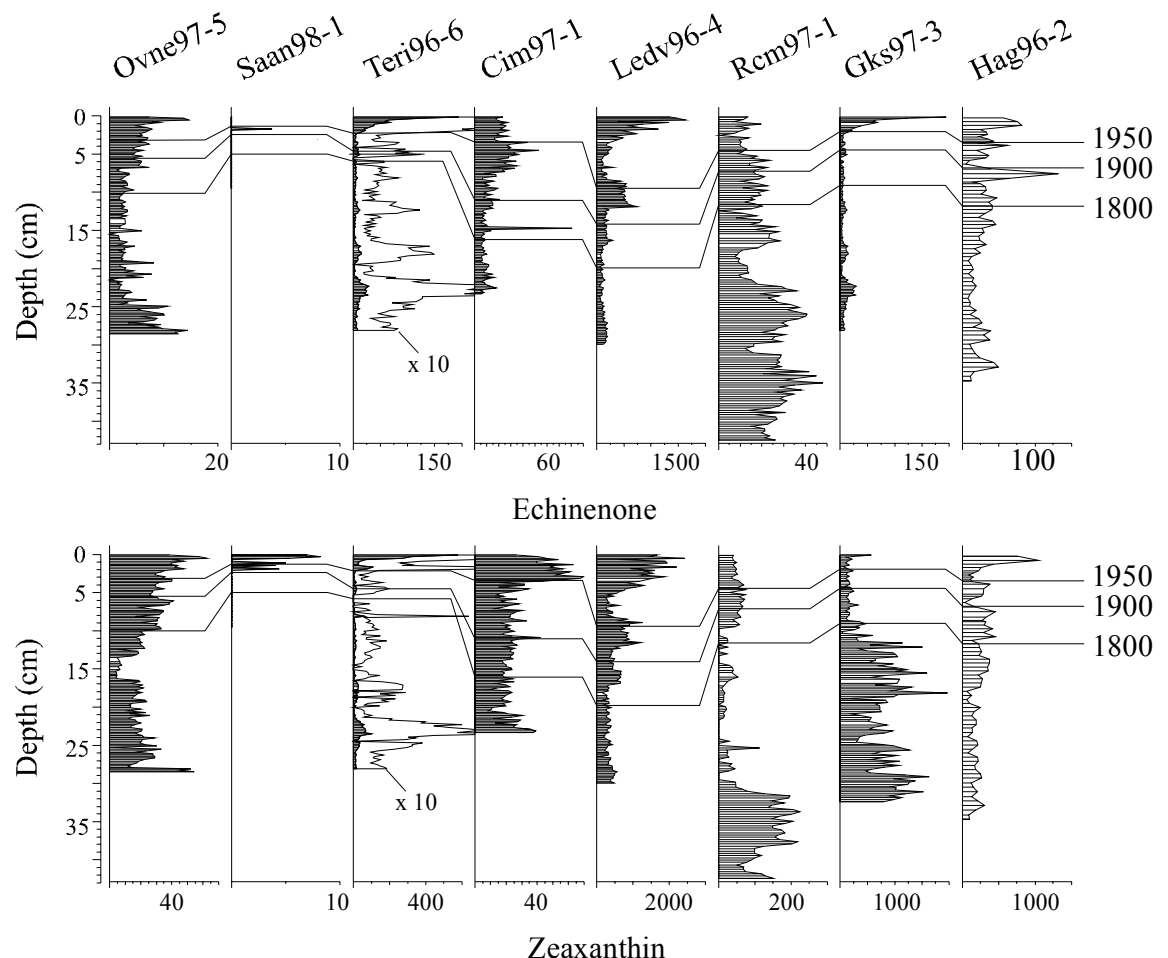

Fig. 4. Depth profiles of selected algal carotenoids belonging to cyanobacteria (see table 1 for an explanation of the core codes).
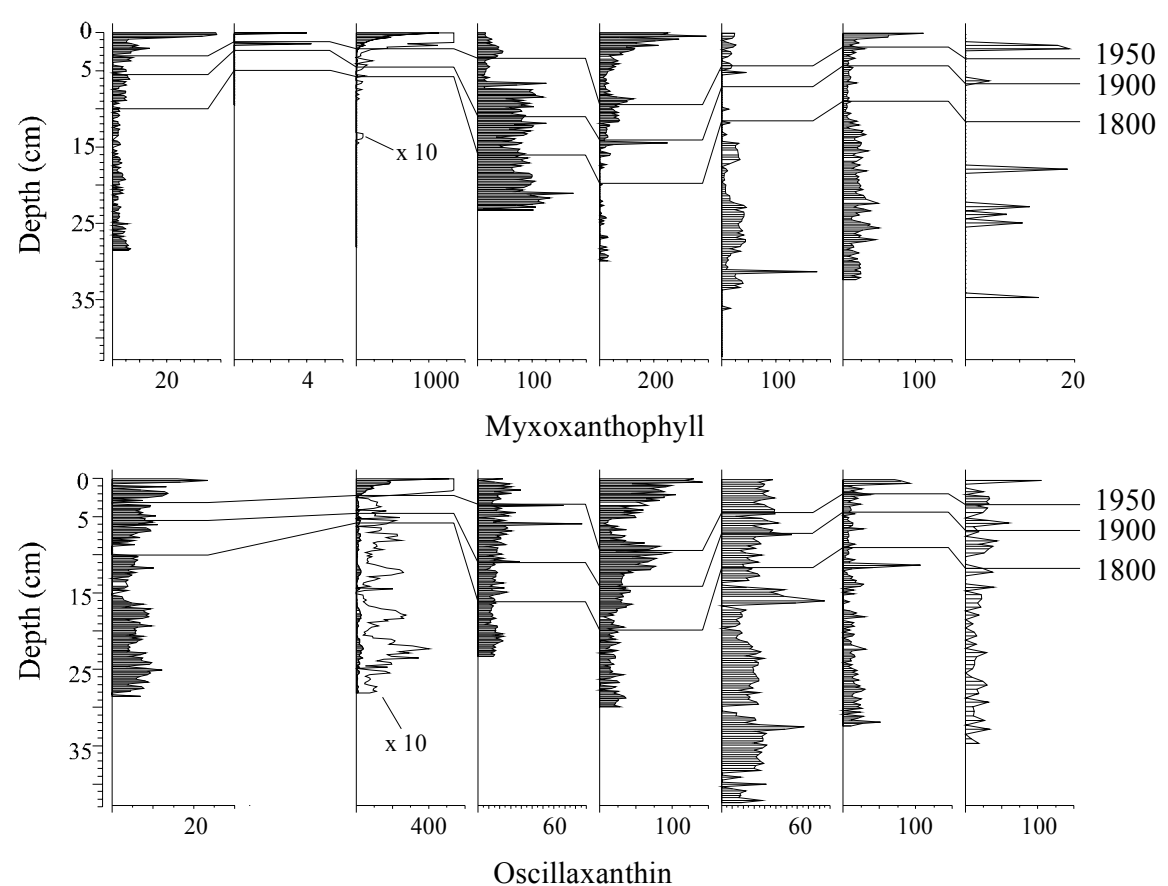

(ca 1950) is shown in: Nižné Terianske and Hagelseewli. No clear trends are evident in Cimera 1, Øvre Neådalsvatn, and Jezero $\mathrm{v}$ Ledvici. On the contrary, a general decrease of $\mathrm{S}$ during very recent times is clearly shown by the cores from Redó and Hagelseewli. Whether or not this reduction is the result of a decrease in atmospheric loading decrease which began at the end of the 1980 s remains an open question. However, the matching of the two trends (the atmospheric and sedimentary sulphur), shown here, as well as in other envi- ronments (e.g. the sub-alpine Lake Candia; Lami et al. 2000) favours the reduction in the atmospheric loading as its cause. As suggested by a study of spherical carbonaceous particles (Lotter et al. 2000, submitted), anthropogenic input of S seems quite clear in Hagelseewli.

\subsection{Pigments (Figs. 3-7)}

Pigment preservation is generally good throughout the cores from all lakes. This is supported by the following evidence: (1) all sediment cores were abundant 

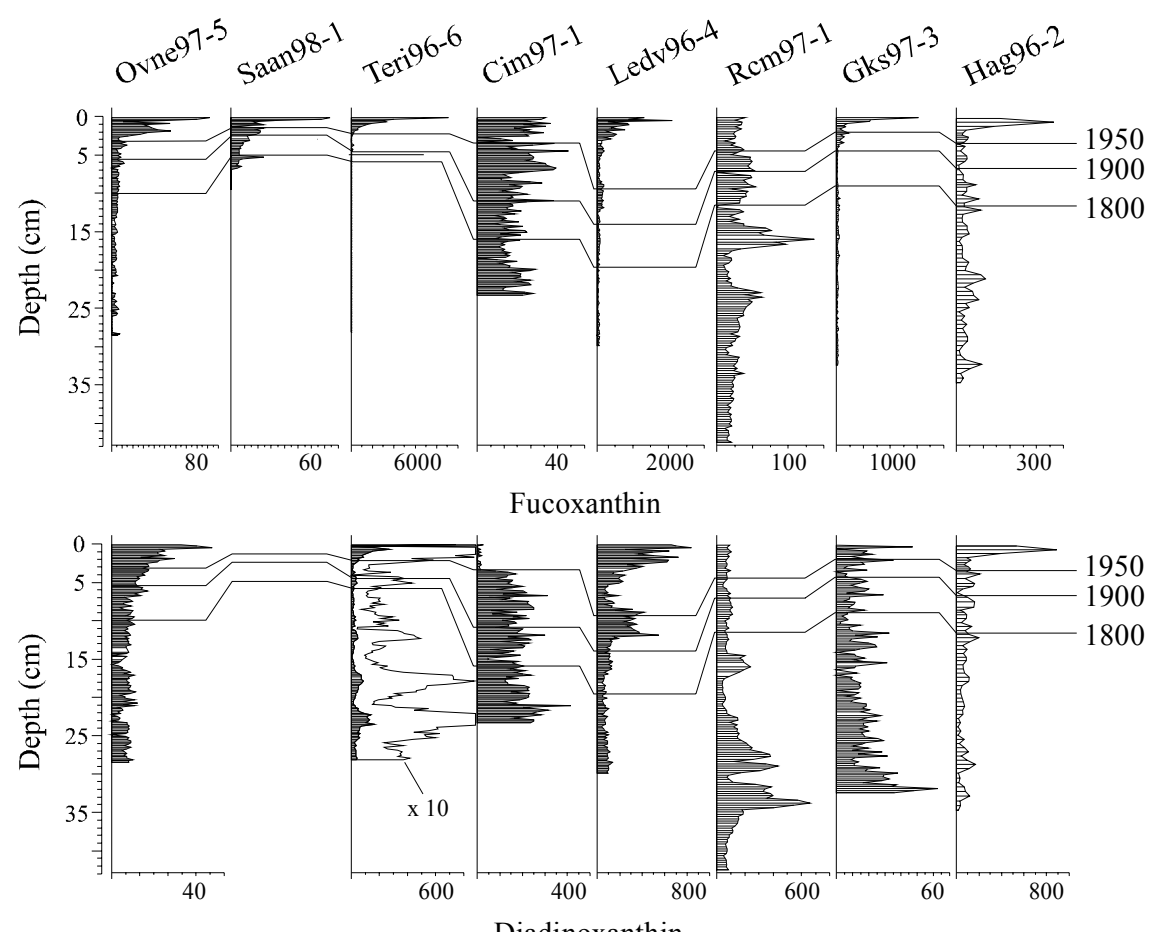

Fig. 5. Depth profiles of selected pigments produced by siliceous algae(Fucoxanthin and Diadinoxanthin) and present in zooplankton (astaxanthin). See table 1 for an explanation of the core codes.

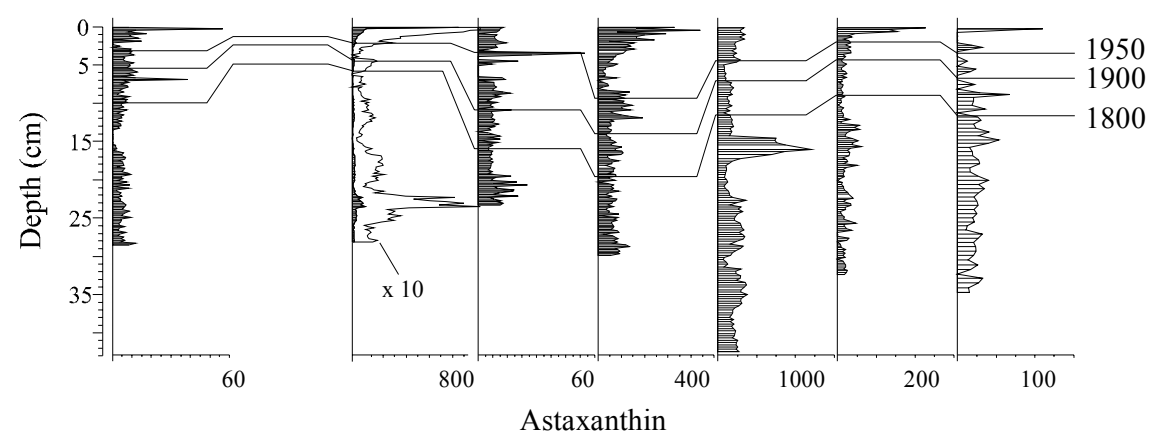

in labile chlorophylls (e.g. Chl- $a$ and $c$ ) and carotenoids (e.g. peridinin, fucoxanthin); (2) in three lakes (Jezero v Ledvici, Hagelseewli and Gossenköllesee) the concentrations of undegraded chlorophylls and some carotenoids (e.g. B-carotene, lutein) in their uppermost 2-3 layers were similar to those found in rather productive lakes, although phaeopigment concentrations were always higher; (3) undegraded chlorophylls generally predominate in fossil deposits only when algal remains are rapidly buried in an anoxic environments (as is the case for Jezero v Ledvici, Gossenköllesee and Hagelseewli); however, all the lakes investigated show the presence of these labile pigments, and (4) for several lakes the pigment concentrations are higher in older strata than modern ones (Core Gks97-3; Core Cim97-1; Core Ovne97-5. Core Rcm97-1; Fig. 3). Finally, because of the extreme environmental conditions, especially the low temperatures of high altitude lakes slow the breakdown of pigments.

Nevertheless, there is a significant evidence for pigment losses by post-depositional degradation in Lake Nižné Terianske, whereas selective degradation of ca- rotenoids and chlorophylls seem to occur in the surface layers of the Spanish lakes Cimera and Redó. In the latter lake a steady decrease of the $430 \mathrm{~nm}: 410 \mathrm{~nm}$ ratio is shown from $14 \mathrm{~cm}$ to the surface (Fig. 3). This implies a slight deterioration of pigment preservation or the onset of a water acidification process (Guilizzoni et al. 1992). Cimera is the only lake in which CD and TC are not correlated in the uppermost $4 \mathrm{~cm}$ (last $\mathrm{ca} 40$ years). At $3 \mathrm{~cm}$ a change in the accumulation rates was also shown (Appleby 2000, this issue). Selective degradation of pigments occurs with carotenoids more degraded than chlorophylls. A more abrupt decrease in the first $4 \mathrm{~cm}$ of the core is observed for $\beta$-carotene. This recent carotenoid decrease parallels in fact a similar decrease in the $430 \mathrm{~nm}: 410 \mathrm{~nm}$ ratio.

The pigment distribution of Lake Saanajärvi (see below) deserves some comments: in this lake pigments are absent from the sediments below 7-8 cm. It is unusual to see sediment with no carotenoids, unless the lake is very warm (tropical) or very shallow and dried out. It is clear that none of these features belong to this rather deep (24 m), subarctic lake. Thus, we do not have any 

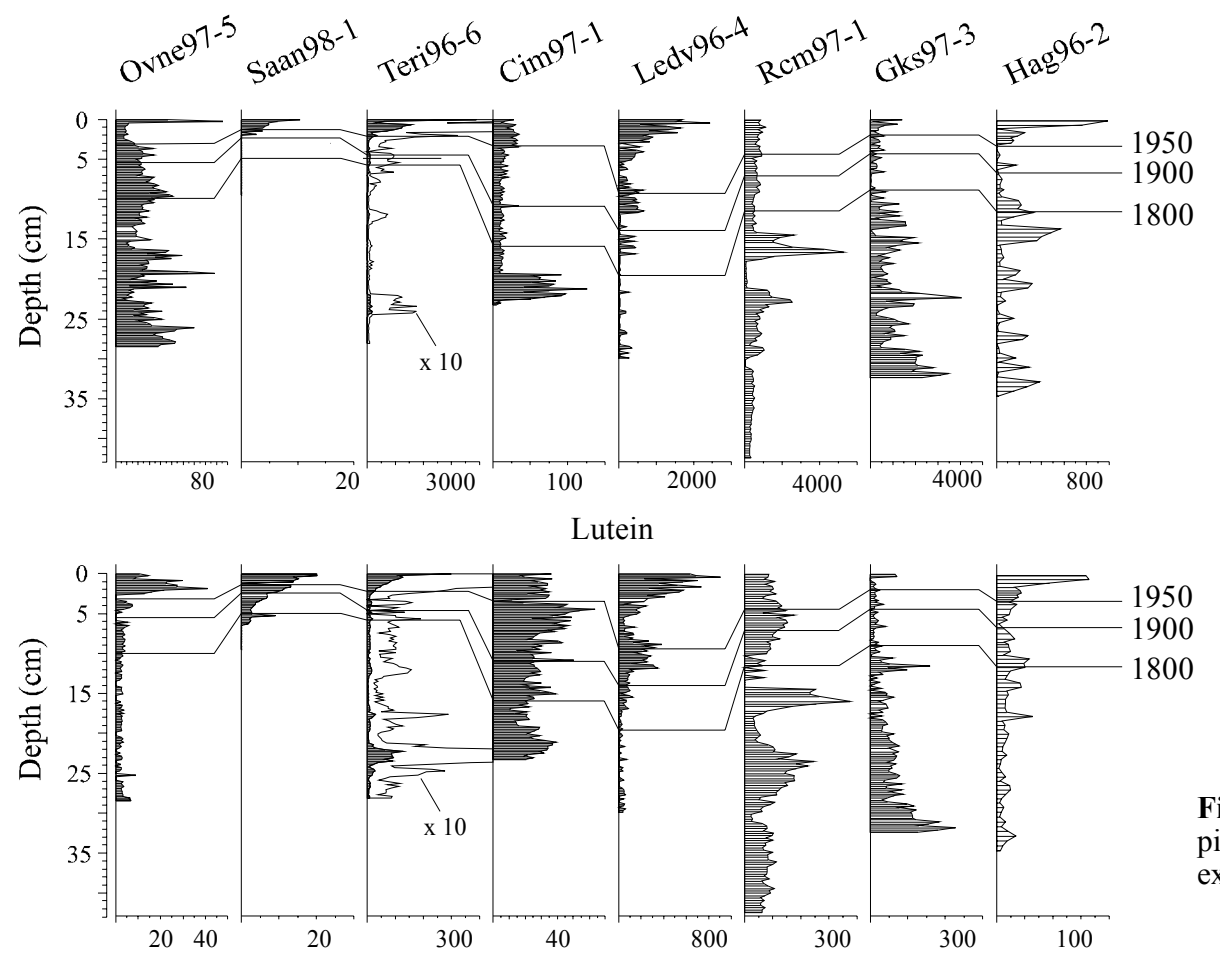

Fig. 6. Depth profiles of selected pigments (see table 1 for an explanation of the core codes).

Alloxanthin

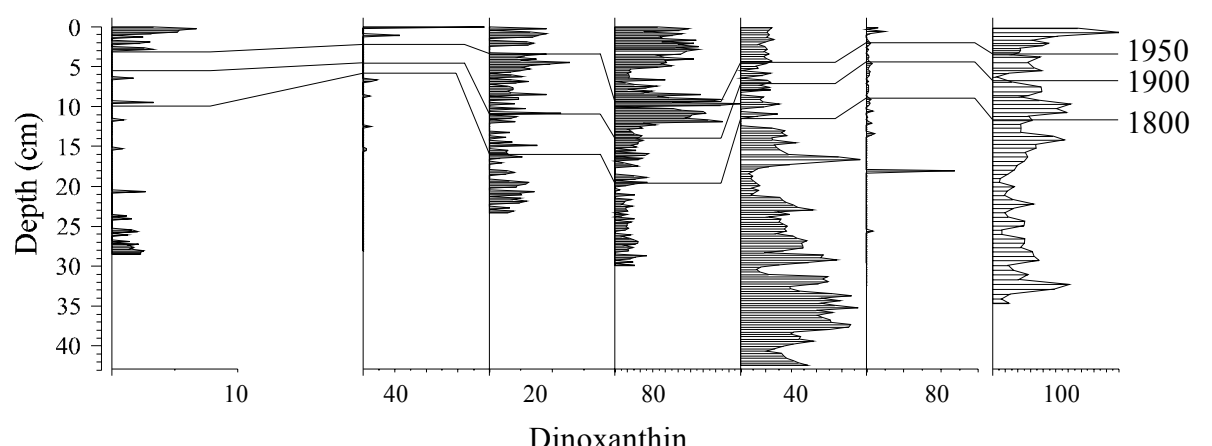

Dinoxanthin

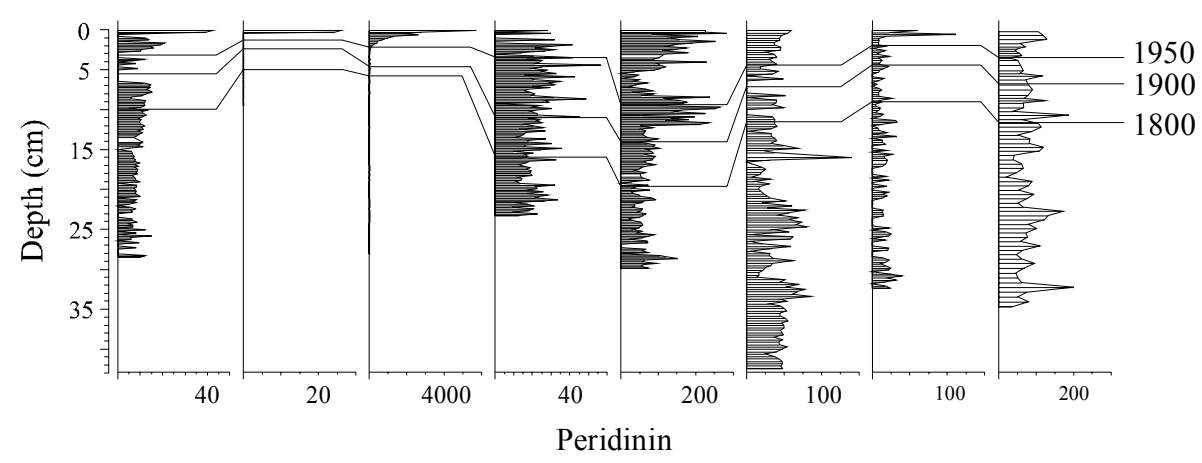

explanation for the absence of pigments in the deepest sediment layers.

Concentrations of chlorophyll derivatives (CD) and total carotenoids (TC) show a recent marked increase in all lakes, except again in lakes Redó and Cimera in which CD concentrations only increase. Very high concentrations of total pigments in the topmost sediment layers are found in Nižné Terianske, Gossenköllesee, Jezero v Ledvici (the highest) and Hagelseewli. Two pieces of evidence indicate that the increase in sedimentary algal pigments is largely the result of increased production, rather than the effect of differences in the autochthonous/allochthonous balance or organic matter dilution. First, the above consideration that a high percentage of the sedimentary organic matter is autochthonous. Second, when the concentrations of organic carbon increase also the pigments increase. Besides, the observed variation in pigments, along the cores, espe- 

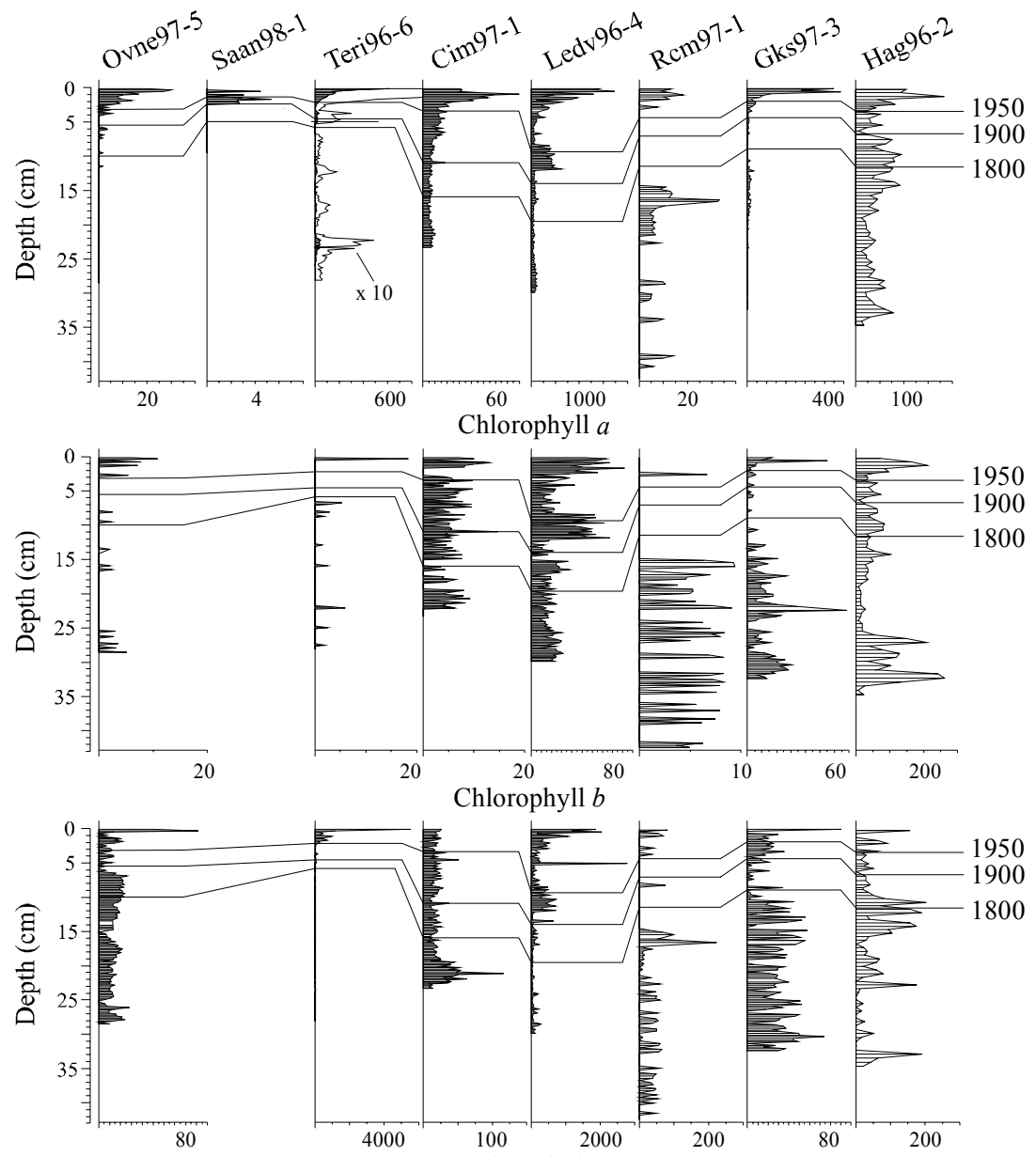

Fig. 7. Depth profiles of selected chlorophylls and their degradation products phaeophorbide- $a$ and phaeophytin- $a$ (see table 1 for an explanation of the core codes).
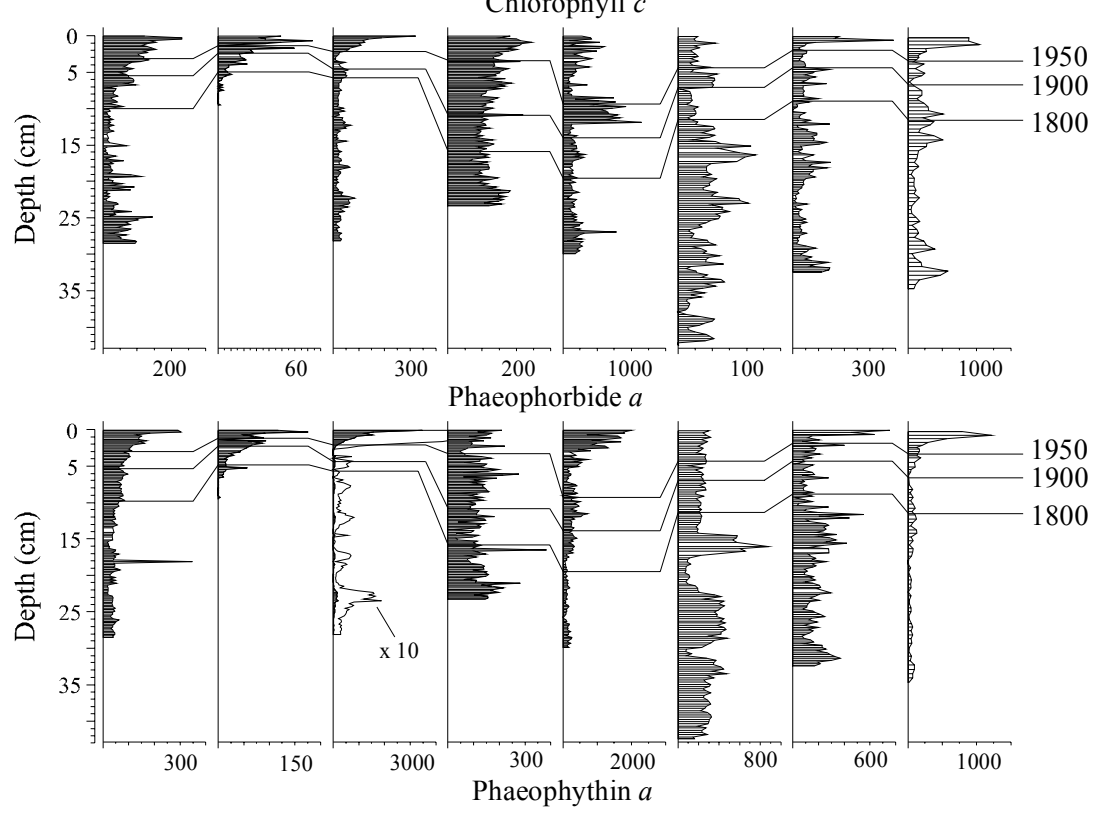

cially during recent times, cannot be ascribed to changed preservation conditions (cf. above discussion).

Extremely low concentrations (the lowest) in TC are measured in the Norwegian Lake Øvre Neådalsvatn probably as a result of allochthonous organic matter di- lution ( $\mathrm{C}: \mathrm{N}$ ratio of $c a$ 18). A low productive environment is also shown by the Finish Lake Saanajärvi. In Nižné Terianske, cyclic behaviour of the pigments, especially the CD, (periodicity of $c a 180 \mathrm{y}$ ), are also observed (Fig. 3). Their cause is unknown. Simpler profi- 
les are seen in Cimera, Øvre Neådalsvatn, Jezero v Ledvici (only three zones but very evident), and Saanajärvi. In contrast, fluctuating profiles of $\mathrm{CD}$ and $\mathrm{TC}$, with many possible biozones are in the following lakes: Nižné Terianske, Redó, Gossenkölle and Hagelseewli.

Oscillaxanthin and myxoxanthophyll (colonial algae) are present in all lakes except Saanajärvi where only a trace of myxoxanthophyll is present. In general, many unknown pigments are present in all lakes except Saanajärvi. Low concentrations of these specific pigments (except in the topmost 1-2 layers) are measured in: Nižné Terianske, Cimera (low content at surface too), Øvre Neådalsvatn and Saanajärvi.

Low diversity of pigments probably reflect a considerable degree of aerobic decomposition of sedimentary organic matter, which may result from a combination of factors including the influx of well oxidised, allochthonous detritus, low water level and consequent disturbance of the sediment, light penetration to the profundal mud, and higher water temperature (Sanger \& Gorham 1970, 1972). All of these phenomena will accompany invasion by wetland vegetation. Pigment numbers below 15 probably signify intense oxidation of the sediment or derivation of the organic matter from totally terrestrial sources. In terrestrial detritus a maximum of c. 10 pigments can be detected in falling leaves and in soil humus layers during autumn coloration, but c.5 peaks are present more commonly.

The presence of alloxanthin (a carotenoid characteristic of strictly planktonic cryptophytes) indicates that total primary production results from phytoplankton. This is not unexpected if we consider that most of the lakes studied are rather deep. This carotenoid could be used to identify the degree of thaw experienced (Smol et al. 1991). Enhanced alloxanthin concentrations should indicate increased ice-free periods. The concentration of this pigment is relatively high near the core surface of Øvre Neådalsvatn, Jezero v Ledvici, Hagelseewli, Nižné Terianske and Saanajärvi. Alloxanthin decreases in Gossenköllesee, and fluctuates in Cimera and Redó. Some authors (Züllig 1982; Pienitz et al. 1992; Leavitt 1993; Leavitt et al. 1994) use the variations of alloxanthin to infer water level changes. However, to make this interpretation in our lakes we must first demonstrate that in lakes with known water level changes, the cryptophyte population varies.

Phaeophorbide- $a$ and astaxanthin, typically pigment indicators of herbivory (grazing) are, except Saanajärvi, usually well represented in all lakes, and highly correlated $(\mathrm{P}<0.001)$. Increasing trends of these pigments are evident in all lakes except Redó. In this lake the two pigments are highly correlated $(\mathrm{r}=0.78)$ and show wide fluctuations with a maximum grazing activity prior AD 1800. Higher concentrations of phaeophorbides are found in Nižné Terianske and Gossenköllesee (near surface), Jezero v Ledvici and Redó.
Pigments from anaerobic purple and green sulphur anaerobic photosynthetic bacteria are detected in Jezero v Ledvici, Hagelseewli and Gossenköllesee. In the former lake, the concentrations are very high. Four main zones are evident. Zone I (core base- $13 \mathrm{~cm}$ ), with very low concentrations; zone II $(12-8 \mathrm{~cm})$, all pigment concentrations increase; zone III $(8-4.5 \mathrm{~cm})$, of reduced pigment concentrations; zone IV (4.5 cm-surface), all pigments increase again, reaching values similar to zone II. The sediments of this lake show the presence of carotenoids belonging to sulphur anaerobic photosynthetic bacteria: rhodopinal (Rhodospirillaceae), not detected in L. Hagelseewli, and others show maximum (Fig. 8) concentrations in zone IV and II. Strong water column stratification or meromictic-like conditions can be inferred from the presence of these carotenoids (Züllig 1985). Almost all the single pigments show high concentrations. During the first half of 1900 a strong increase of pigments is shown.

In Core Hag 96-2, isorenieratene (from the green bacteria, Chlorobiaceae) was always detected, whereas others pigment from purple bacteria (e.g. okenone) are regularly present only from $7 \mathrm{~cm}$ to surface. Modern bottom-water oxygen depletion has been demonstrated by Ohlendorf et al. (2000, this issue).

Among the carotenoids from sulphur anaerobic bacteria isorenieratene is also dominant in Gks97-3.

\section{CONCLUSIONS}

As a whole these European alpine lakes do not show common palaeoenvironmental responses in terms of timing and onset of the inferred changes in primary production, except for the general increasing trend of the pigment concentrations during the most recent decades. We think that a climatic signal, i.e. the increase of temperature, affects this trend factor: in fact, other papers in this volume report evidence for this impact, which is often superimposed on human impact. For most of the study environments the diagenetic process in recent sediment strata unless - diagenesis has been more intensive during recent decades - cannot be use this as an argument.

From our experience of studying remote alpine lakes, the concentrations of pigments are mainly the result of benthic production (if combined with relatively low water column chlorophyll concentrations) and thus, the "high" concentrations is not necessarily representative of "high productivity" conditions. In some remote lakes, high pigment concentrations may arise because of differences among lakes and periods in the flux of terrestrial organic and inorganic matter. In lakes like the MOLAR ones, with very low allochthonous organic matter input, the pigments concentrations are consequently high, also because preservation is generally good and the effect from the allochthonous pigment dilution is small. In addition, organic matter is well preserved and climate change remains a speculative although plausible me- 


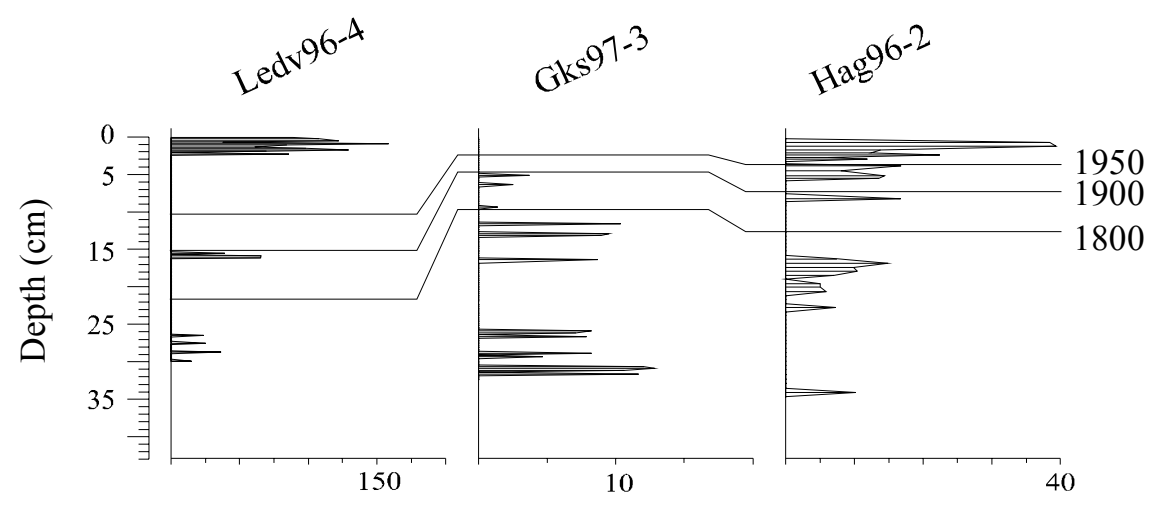

Okenone
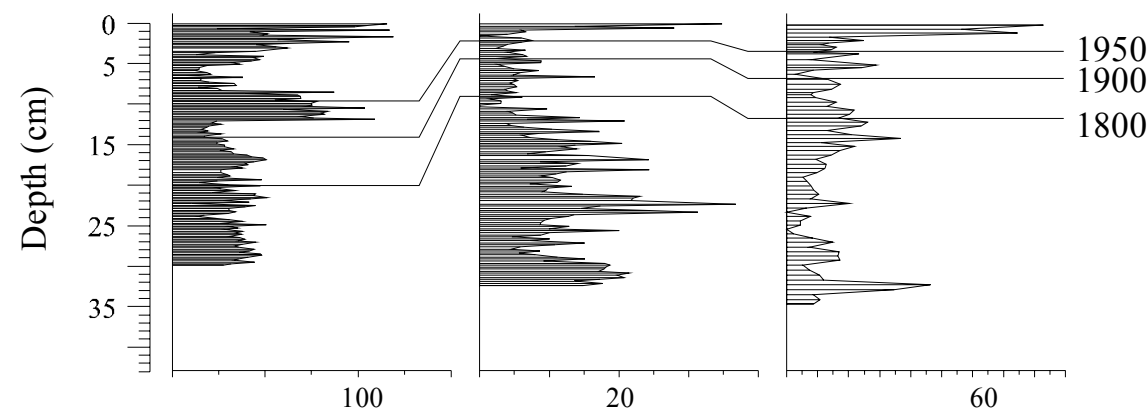

1950

1900

Fig. 8. Depth profiles of selected pigments produced by sulphur photosynthetic bacteria (see table 1 for an explanation of the core codes).

Isorenieratene
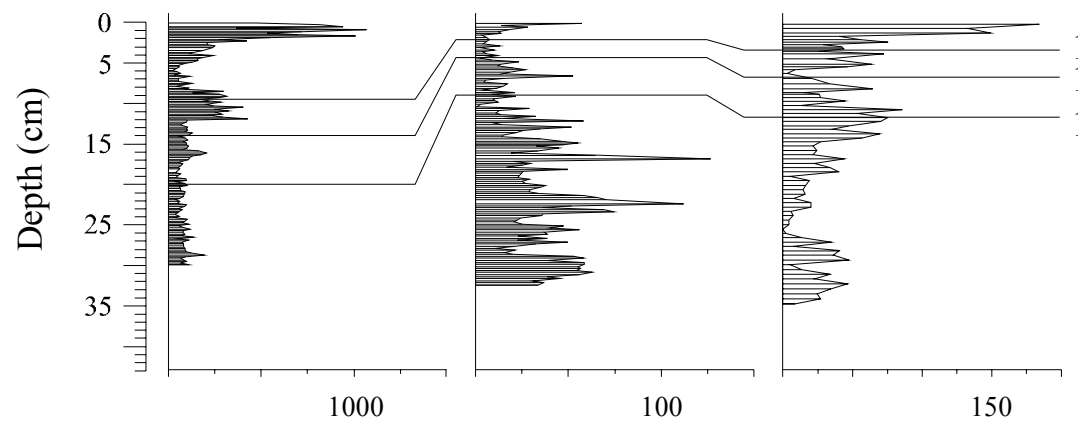

1950

1900

1800

Total sulphur phosynthetic bacteria

chanism to explain this increase as well as peaks in pigments in the oldest sediments.

The oscillations in pigment concentration are interesting, especially in CD, TC, ß-carotene, diadinoxanthin, echinenone, in Nižné Terianske and Redó from Slovak and Spain, respectively. This latter lake is amongst the highest as regard the concentration in sedimentary fossil pigments. As its morphometry is very different from the others (e. g. max depth of $70 \mathrm{~m}$ ), and with a deep and stable thermal stratification, the sedimentation processes are probably different from those of other study lakes. The very different sedimentation rates (max in Jezero $\mathrm{v}$ Ledvici and minimum in Saanajärvi) among the study lakes prevent a more detail comparison.

ß-carotene, the recommended indicator carotenoids of algal biomass (Leavitt 1993), is much more abundant in pre- 1800 periods than at present time in Redó and
Gossenköllesee (Fig. 3). Cimera, Hagelseewli and Nižné Terianske also have a high peak of this carotenoid in old sediment layers. Cyanobacteria are well represented throughout the core in Jezero v Ledvici (Fig. 4 ), but all lakes host a rich algal community of this group in recent times. Filamentous cyanobacteria (e.g. Oscillatoria spp.), are particularly abundant in Nižné Terianske at surface and in Jezero v Ledvici (Fig. 4).

Seasonal anoxia in deep waters is a feature of three lakes: Hagelseewli, Jezero v Ledvici and Gossenköllesee (Fig. 8). This condition is clearly consistent with strong stratification and a long period of complete ice cover (see papers in this volume); this is especially true for Hagelseewli for which harsh meteorological conditions often prevail also during summer (Lotter et al. 2000, this issue). On the other hand, during the last 800 years history of Gossenköllesee, as revealed by a pa- 
laeolimnological investigation, human impact (e.g. landuse, sheep and cattle farming) was predominant (Kamenik et al. 2000, this issue).
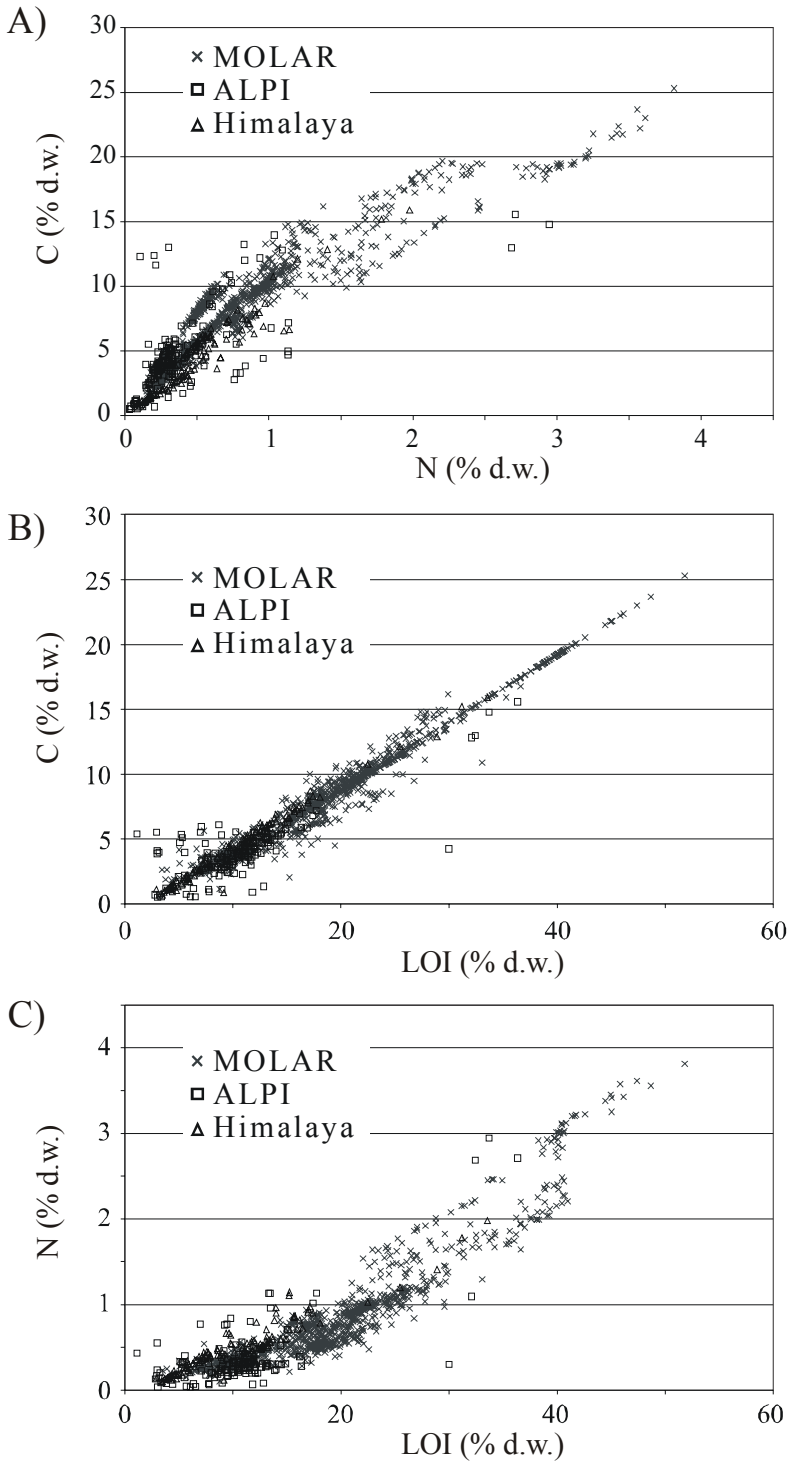

Fig. 9. Relationships of between organic carbon (C), nitrogen (N) and organic matter (LOI), from the study lakes (MOLAR) and comparison with a suite of lakes from the Alps (ALPI) and the Himalayas.

High significant correlations are shown by LOI, nitrogen and organic carbon, and between $\mathrm{C}$ and $\mathrm{N}$ (Fig. 9). The slopes of these curves are however different from other alpine lakes in different geographical regions (Himalayas, Alps). Among the MOLAR lakes, Jezero v Ledvici is an outliner because the regression line have the same slope, but a different intercept. This difference is easily explained by the high content of carbonates in Jezero v Ledvici sediment due to a calcareus bedrock.

Finally, Hagelseewli shows the highest content in sulphur: $c a 10$ fold higher in a sub-surface core layers and this as shown from another study (Lotter et al. 2000 submitted ) is clearly of anthropogenc origin.

\section{ACKNOWLEDGMENTS}

We are grateful to P.R. Leavitt, University of Regina, Saskatchewan, Canada for constructive criticism of the manuscript and to N. Cameron, Univ. College London, London, UK for the revision of the MS. Thanks also to P. Appleby and R. Thompson for providing the chronology of all lakes, and the core-to-core correlations. C, N and LOI data of Lake Gossenköllesee were provided by C. Kammenik. Besides, LOI data of the remaining lakes were analysed by the local site operators. This work was supported by MOLAR (Mountain Lake Research) Project EC Contract No. ENV4 CT950007.

\section{REFERENCES}

Appleby, P.G. 2000. Radiometric dating of sediment records in European mountain lakes. In: A. Lami, N. Cameron \& A. Korhola (Eds), Paleolimnology and ecosystem dynamics at remote European Alpine lakes. J. Limnol., 59 (Suppl. 1): 1-14.

Brown, S.R., H.J. McIntosh \& J.P. Smol. 1984. Recent paleolimnology of a meromictic lake: fossil pigments of photosynthetic bacteria. Verh. int. Ver. Limnol., 22: 1357-1360.

Callot, H.J. 1991. Geochemistry of chlorophylls. In: H. Scheer (Ed.), Chlorophylls. CRC Press, Ann. Arbor: 340-364.

Cuddington, K. \& P.R. Leavitt. 1999. An individual-based model of pigment flux in lakes: implications for organic biogeochemistry and paleoecology. Can. J. Fish. aquat. Sci., 56: 1964-1977.

Gorham, E., J.W.C. Lund, J.E. Sanger, \& W.E. Dean. 1974. Some relationships between algal standing crop, water chemistry, and sediment chemistry in the English lakes. Limnol. Oceanogr. 19: 601-617.

Guilizzoni, P. \& A. Lami. 1999. Palaeoclimate and anthropogenic impact on aquatic ecosystems as inferred from the analyses of natural archives. In: A. Farina (Ed.), Perspective in Ecology, Backhuys Publishers, Leiden: 87-98.

Guilizzoni, P., A. Lami \& A. Marchetto. 1992. Plant pigment ratios from lake sediments as indicators of recent acidification in alpine lakes. Limnol. Oceanogr., 37: 1565-1569.

Guilizzoni, P., G. Bonomi, G. Galanti \& D. Ruggiu. 1983. Relationship between sedimentary pigments and primary production: evidence from core analyses of twelve Italian lakes. Hydrobiologia , 103: 103-106.

Jeffrey, S.W., R.F.C. Mantoura \& S.W. Wright (Eds). 1997. Phytoplankton pigments in oceanography.UNESCO Publishing., Paris: $661 \mathrm{pp}$.

Kamenik, C., K.A. Koinig, R. Schmidt, P.G. Appleby, J.A. Dearing, A. Lami, R. Thompson, R. Psenner. 2000. Eight hundred years of environmental changes in a high Alpine lake (Gossenköllesee, Tyrol) inferred from sediment records. In: A. Lami, N. Cameron \& A. Korhola (Eds), Paleolimnology and ecosystem dynamics at remote European Alpine lakes. J. Limnol., 59 (Suppl. 1): 43-52.

Lami, A., F. Niessen, P. Guilizzoni, J. Masaferro \& C.A. Belis. 1994. Palaeolimnological studies of the eutrophication of volcanic Lake Albano (central Italy). J. Paleolimnol., 10: 181-197.

Lami, A., P. Guilizzoni, D. Ruggiu, B. Polli, M. Simona \& A. Barbieri. 1992. Role of pigments on algal communities and photosynthesis. Aquatic Sciences, 54: 321-330.

Lami, A., P. Guilizzoni, R. Bettinetti, C.A. Belis, M. Manca, P. Comoli \& A. Marchetto. 1996. Biological records of 
late Pleistocene and Holocene environmental changes from two Italian crater lake sediments: results from an European interdisciplinary reserch project (PALICLAS). Il Quaternario, Italian Journal of Quaternary Sciences, 9: 711-720.

Lami A., P. Guilizzoni, D.B Ryves, V.J. Jones, A. Marchetto, R.W. Battarbee, C.A. Belis, R. Bettinetti, M. Manca, P. Comoli, A. Nocentini \& L. Langone. 1997. A late Glacial and Holocene record of biological and environmental changes from the crater Lake Albano, Central Italy: and interdisciplinary European project (PALICLAS). Water, Air and Soil Pollution, 99: 601-613.

Leavitt, P.R. 1993. A review of factors that regulate carotenoid and chlorophyll deposition and fossil pigment abundance. J. Paleolimnol., 9: 109-127.

Leavitt, P.R., D.L. Findlay, R.I. Hall \& J.P. Smol. 1999. Algal responses to dissolved organic matter loss and $\mathrm{pH}$ decline during whole-lake acidification: evidence from paleolimnology. Limnol. Oceanogr., 44: 757-773.

Leavitt, P.R., P.R. Sanford, S.R. Carpenter \& J.F. Kitchell 1994. An annual fossil record of production, planktivory and piscivory during whole-lake manipulations. J. Paleolimnol., 11: 133-149.

Lotter, A.F., P. Appleby, J.A. Dearing, J.A. Grytnes, W. Hofmann, C. Kamenik, A. Lami, D.M. Livingstone, C. Ohlendorf, N. Rose, M. Sturm \& R. Thompson. 2000. The record of the last 200 years in the sediments of Hagelseewli (2339 $\mathrm{m}$ asl), a high-elevation lake in the Swiss Alps. J. Paleolimnol. (submitted).

Mantoura, R.F.C. \& C.A. Llewellyn.1983. The rapid determination of algal chlorophyll and carotenoid pigments and their breakdown products in natural waters by reversephase-high-performance liquid chromatography. Anal. Chim. Acta, 15(2): 297-314.

Meyers, P.A. \& E. Lallier-Vergès. 1999. Lacustrine sedimentary organic records of Late Quaternary. J. Paleolimnol., 21:345-372.

Mitchell, M.S., J.S. Owen \& S.C. Schndler. 1990. Factors affecting sulfur incorporation into lake sediments: paleoecological implications. J. Paleolimnol., 4: 1-22.
Ohlendorf, C., C. Bigler, G.-H. Goudsmit, G. Lemcke, D.M. Livingstone, A.F. Lotter, B. Müller \& M. Sturm. 2000. Causes and effects of long periods of ice cover on a remote high Alpine lake. In: A. Lami, N. Cameron \& A. Korhola (Eds), Paleolimnology and ecosystem dynamics at remote European Alpine lakes. J. Limnol., 59 (Suppl. 1): $65-80$.

Pienitz, R., I.R. Walker, B.A. Zeeb, J.P. Smol \& P.R. Leavitt. 1992. Biomonitoring past salinity changes in an athalassic subarctic lake. Int. J. Salt Lake Res., 1: 91-123.

Sanger, J.E. \& E. Gorham. 1970. The diversity of pigments in lake sediments and its ecological significance. Limnol. Oceanogr., 15:59-69.

Sanger, J.E. \& E. Gorham. 1972. Stratigraphy of fossil pigments as a guide to the post glacial history of Kirchner Marsh, Minnesota. Limnol. Oceanogr., 17: 840-854.

Smol, J.P. 1990. Paleolimnology: recent advances and future challenges. Mem. Ist. ital. Idrobiol., 47: 253-276.

Smol, J.P., I.R. Walker \& P.R. Leavitt. 1991. Paleolimnology and hindcasting climatic trends. Ver. int. Ver. Limnol., 24 : 1240-1246.

Straškrabová, V., C. Callieri \& J. Fott (Eds). 1999. Pelagic food web in mountain lakes (Mountain Lakes Research Program). J. Limnol., 58(2): 77-222.

Swain, E.B. 1985. Measurements and interpretation of sedimentary pigments. Freshwat. Biol., 15: 53-75.

Züllig, H. 1982. Untersuchungen über die Stratigraphie von Carotinoiden im geschichteten Sediment von 10 Schweizer Seen zur Erkundung früherer PhytoplanktonEntfaltungen. Schweiz. Z. Hydrol., 44: 1-98.

Züllig, H. 1985. Pigmente phototropher Bakterien in Seesedimenten und ihre Bedeuntung für die Seenforschung. Schweiz. Z. Hydrol., 47: 87-126.

Züllig, H. 1986. Carotenoids from plankton and photosynthetic bacteria in sediments as indicators of trophic changes in Lake Lobsigen during the last 14000 years. Hydrobiologia, 143: 315-319. 